\title{
Effect of Climate Change on Insect Behaviour
}

\author{
Lipsa Dash ${ }^{*}$ \\ MSSSoA, Centurion University of Technology and Management, \\ Paralakhemundi, Odisha, India \\ *Corresponding author
}

\section{Keywords}

Global warming, Climate change, Insect pests

\section{Article Info}

Accepted: 08 January 2020 Available Online: 10 February 2020

\section{A B S T R A C T}

Global warming is a great concern throughout the world. The ill effects of global warming like change in climate, temperature, rainfall, humidity, level of carbon di-oxide has been found to have both positive and negative effects on insects, which in turn reduces the effectiveness of crop protection measures. This creates the need for global warming to be taken as an important criterion in Entomology. Being poikilothermic in nature insects are greatly affected by changing temperature. Insect will experience additional life cycles with rapid growth rate. As a result of changes in the population dynamics including distribution and migration the reliability on current insect pest ETL will be reduced. Increased insect pests outbreak will affect agricultural production. Research on basic biology of insect, population dynamics and behavior patterns should be focused to ascertain the effect of global warming on insect behavior.

\section{Introduction}

Generally global warming refers to an increase in average global temperatures. Climate change has been recognized globally as the most impending and pressing critical issue affecting mankind survival. The fifth assessment report (AR5) by the 'Intergovernmental Panel on Climate Change' (IPCC) reported that each of past three decades has been successively warmer at the Earth's surface and the decade of 2000's has been the warmest. The globally averaged combined land and ocean data as calculated by a linear trend, showed a warming of $0.85(0.65-1.06){ }^{\circ} \mathrm{C}$ over the period 1880 to 2012 (IPCC 2013). The major cause of climate change is increase in the concentration of greenhouse gases (GHG) viz., carbon dioxide $(\mathrm{CO} 2)$, methane $(\mathrm{CH} 4)$ and nitrous oxide (NO2) as a result of human activities from pre-industrial era. These gases keep the earth warm and cause global warming or green house effect. Global warming is caused by natural as well as human activities. There are number of natural 
factors responsible for climate change. Some of the most prominent are volcanoes, ocean currents, forest fire etc. Among human activities, emissions of green house gases, industrialization, deforestation, fuel burning, etc are most important factor contributing towards global warming. It is not new that global warming can affect agriculture through their direct and indirect effects on the crops, soils, livestock and pests. Changed climatic conditions will also change the current crop pest scenario.

\section{Effects of increased temperature on insects}

Insects are cold-blooded organisms - the temperature of their bodies is approximately the same as that of the environment. The effect of rising temperature on insect can be direct, through the influence of climatic factors on the insects' physiology and behavior or indirect, as mediated by host plants, competitors or natural enemies (Thomson et al., 2010). Therefore, temperature is probably the single most important environmental factor influencing insect behaviour, distribution, development, survival and reproduction. Some researchers believe that the effect of temperature on insects largely overwhelms the effects of other environmental factors (Bale et al., 2002). It has been estimated that with an increase of $2 \mathrm{oC}$ temperature, insects might experience one to five additional life-cycles per season (Yamamura and Kiritani 1998). Based on evidence developed by studying the fossil record some researchers conclude that the diversity of insect species and the intensity of their feeding have increased historically with increasing temperature. At higher temperatures, aphids have been shown to be less responsive to the aphid alarm pheromone they release when under attack by insect predators and parasitoids - resulting in the potential for greater predation (Awmack et al., 1997). Climate change will have a major effect on geographic distribution of insect pests and low temperatures are often more important than high temperatures in determining geographical distribution of insect-pests. Increasing temperatures may result in a greater ability to overwinter in insect species limited by low temperatures at higher latitudes, extending their geographical range (EPA, 1989; Hill and Dymock, 1989), and sudden outbreaks of insect pests can wipe out certain crop species, and also encourage the invasion by exotic species (Kannan and James, 2009). Increased temperature has resulted in increased northward migration of some insects, insect development rate and oviposition, potential for insect outbreaks, invasive species introductions and insect extinctions. Global warming has lead to earlier infestation by Helicoverpa zea in North America (EPA, 1989), and H. armigera in North India (Sharma et al., 2010), resulting in increased crop loss. Rising temperatures are likely to result in availability of new niches for insect-pests. Temperature has a strong influence on the viability and incubation period of $H$. armigera eggs (Dhillon and Sharma, 2007).

\section{Case study}

\section{Spruce bark beetle}

2.4 to $3.8^{0}$ rise in temperature due to climate change resulted in Spatio - temporal changes in the life cycle of bark beetle. It resulted in the formation of viable population leading to heavy damage to crops (Anna Maria Jonsson et al., 2009)

\section{Impact of rising $\mathrm{CO}_{2}$ levels on insects}

Elevated $\mathrm{CO}_{2}$ levels are likely to influence the crop physiology through increased photosynthetic activity. This would, in turn, affect insects indirectly through the changes of plants and vegetation in quantity as well as 
in quality. Global warming may be attributed for Helicoverpa armigera to attain the pest status of vegetables and recent outbreaks of rice bugs and fruit bugs in Japan (Kiritani 2005). Elevated CO2 concentration increases food consumption by caterpillars, reproduction of aphids while it decreases insect development rates, response to alarm pheromones by aphids, parasitism and effectiveness of transgenics developed with Bacillus thuringiensis (Das et al., 2011).

\section{Case study}

\section{Influence of elevated $\mathrm{CO}_{2}$ on gram pod} borer

Alteration of food quality of chickpea due to elevated $\mathrm{CO} 2$ stimulates the growth of pod borer which leads to increased food consumption, gain in larval weight, more faecal matter production, increased pupal weight and total larval duration. (Abdul Khadar et al., 2014).

\section{Impact of precipitation on insects}

High humidity favours the development of some insects Eg: Aphids. Thrips and White flies are sensitive to heavy precipitation and are removed and killed by heavy rains. Out breaks of Amsacta moorei is directly related to heavy and frequent rain (Saini et al., 2010).

\section{Case study}

\section{Brown Plant Hopper}

The abundance of BPH without precipitation is found to be normal. With an increase in $10 \%$ precipitation more than normal it is abundant. But with an increase in $10 \%$ precipitation and temperature of $1{ }^{0} \mathrm{C}$ successively it has been found to multiply enormously. Global warming has lead to the increased risk and abundance of invasive pest such as Aceria guerreronis, Aleurodicus disperses, Paracoccus marginatus, Ceratovacuna lanigerum.

\section{Effect of global warming on insect biology}

The life span of Japanese beetle, Popillia japonica a major pest of soybean, is prolonged by $8.25 \%$ when fed on foliages developed under elevated $\mathrm{CO}_{2}$. Also females fed on such foliages laid approximately twice as many eggs as compared to females fed on foliages grown under normal ambient conditions. Life cycle of Aphis gossypii Glover ranges from 20-22 days at 10-25 0C, but at $300 \mathrm{C}$ it will take only 6-9 days to complete the life cycle. In the cricket, Gryllus texensis, 6 days of elevated temperatures resulted in increased egg laying, faster egg development and greater mass gain. Global climate change is projected to increase temperature of the upper soil $(0-5 \mathrm{~cm})$ by $1.6-3.4{ }^{\circ} \mathrm{C}$ by 2100 , which is likely to have several effects on soil insects such as Sitona $s p p$, root weevils that are important in lentil in West Asia. Higher temperatures could speed up egg development, resulting in more than one generation per year of the pest (Scott et al., 2010).

\section{Effect on parasitism}

Studies suggest that higher temperatures increase the probability of parasitoid killed by the host. Parasitism of the caterpillar Spodoptera littoralis by the parasitoid Microplitis rufiventris is less at $27^{\circ} \mathrm{C}\left(80.6^{\circ} \mathrm{F}\right)$ than at $20^{\circ} \mathrm{C}\left(68^{\circ} \mathrm{F}\right)$ (Thomas and Blanford 2003). Natural enemies of the spruce budworm, Choristoneura fumiferana, are less effective at higher temperatures (Harrington et al., 2001). Temperature not only affects the rate of insect development, but also has a profound effect on fecundity and sex ratio of parasitoids (Dhillon and Sharma 2008, 2009). Oriental armyworm, Mythimna separate population increases during extended periods of drought (which is detrimental to the natural 
enemies), followed by heavy rainfall because of the adverse effects of drought on the activity and abundance of natural enemies of this pest (Sharma et al., 2002).

\section{Effect of climate change on expression of resistance to insect-pests}

Host plant resistance to insects is one of the most environmental friendly components of pest management. However, climate change may alter the interactions between the insectpests and their host plants (Bale et al., 2002; Sharma et al., 2010). Climate change may result in breakdown of resistance to certain insect pests. Sorghum varieties exhibiting resistance to sorghum midge, Stenodiplosis sorghicola in India become susceptible to this pest under high humidity and moderate temperatures (Sharma et al., 1999). Chemical composition of some plant species changes in direct response to biotic and abiotic stresses as a result, their tissues become less suitable for growth and survival of insect-pests (Sharma 2002).

\section{Effect on insect pheromones}

Pheromones are utilized by insects for several purposes, including alarm signalling and sexual communication. It was found that when $\mathrm{CO}_{2}$ was elevated, aphids Chaitophorus stevensis did not disperse readily, but when $\mathrm{O}_{3}$ was elevated, aphids exhibited an extreme dispersal response. The researchers think this escape behavior may explain the larger aphid populations observed under enriched $\mathrm{O}_{3}$ conditions (Edward et al., 2004).

\section{Effect on insect coloration}

Insect coloration is the phenomenon of adoption to maintain the heat. Scientists have noticed that warming climate is changing ladybugs of the coast of Netherlands from black to red. Red reflects more energy hence ladybugs stay cool. The difference between red and black in ladybugs is only one protein, so as far as genetic adaptations concerns, it's an easy switch.

\section{Effect of climate change on effectiveness of transgenic plants}

Interestingly, such changes have important implications for the use of certain transgenic plants that are resistant to insects. It was observed that growing these transgenic plants in elevated carbon dioxide resulted in a nearly 25 per cent reduction of the expression of these proteins. This reduction allowed beet armyworms, Spodoptera exigua to survive on these plants, which would likely lead to the rapid selection of pest populations resistant to these proteins.

\section{Climate change may affect our strategies for pest management}

The relationship between the crop protection costs and the resulting benefits will change as results of global warming and climate change. Global warming will also reduce the effectiveness of host plant resistance, transgenic plants, natural enemies, biopesticides, and synthetic chemicals for pest management (Sharma, 2010). Casteel et al., (2009) reported that global warming could cause another deleterious effect in the form of deactivation of some genes responsible for the production of volatile substances that are used by plants to attract the natural enemies of the herbivorous insects. Increased temperature and UV radiation and low relative humidity may render many of these control tactics to be less effective, and therefore, there is a need to:

Understand the changes in expression of resistance to insect-pests, and identify stable sources of resistance, and pyramid the resistance genes in commercial cultivars. 
Study the effects of global warming on the efficacy of transgenic crops in pest management.

Assess the efficacy of various pest management technologies under diverse environmental conditions, and develop appropriate strategies for pest management to mitigate the effects of climate change.

In conclusion, global warming is the international problem. Agricultural business is likely to suffer losses in long run due to climate change and new emerging pest scenario. Hence pest management tactics are to be improved according to the prevailing condition. Productive insects and natural enemies are affected to a greater extent. So, resistant strains are to be developed. IPM principles will be required to be followed more strictly in the future scenario of global warming. Reduction in use of pesticides will also help in reducing carbon emissions. Historical data should be taken into consideration while formulating the experiments and standardization of protocols. Further research has to be carried out to manipulate the effects with a focus to improve the effectiveness of crop protection practises.

\section{References}

Abdul Khadar B, Prabhuraj A, Srinivasa Rao M, Sreenivas AG, Naganagoud A. Influence of elevated $\mathrm{CO} 2$ associated with chickpea on growth performance of gram caterpillar, Helicoverpa armigera. Applied ecology and Environmental research. 2014; 12(2):345-353.

Anna Maria Jonsson, Gustar Appelberg, Susanne Harding and Lars Barring. Spatio - temporal impact of climate change on the activity and voltinism of Spruce bark beetle, Ips typographus. Global change Biology. 2009; 15:486-499.

Casteel, C.L., Berenbaum, M.R. and Delucia, E. H. (2009). Does elevated carbon dioxide universally alter phytohormone signaling? Entomological Society of America annual meeting, December 14, 2009, Indianapolis.

Das, D.K., Singh, J. and Vennila, S. (2011). Emerging Crop Pest Scenario under the Impact of Climate Change. J. Agril. Phy., $11: 13-20$

Dhillon MK and Sharma HC 2007. Effect of storage temperature and duration on viability of eggs of Helicoverpa armigera (Lepidoptera: Noctuidae). Bull. Ento. Res. 97: 55-59.

Dhillon MK and Sharma HC 2008. Temperature and Helicoverpa armigera food influence survival and development of the ichnemonid parasitoid, Campoletis chlorideae. Ind. J. Pl. Protect. 36: 240-44.

Dhillon MK and Sharma HC 2009. Temperature influence the performance and effectiveness of field and laboratory starins of the ichneumonid parasitoid Campoletis chlorideae. Biocontrol 54: 743-50.

Edward, B.M., Michelle, N.T., Caroline, S.A. and Richard, L.L. (2004). Divergent pheromone mediated insect behaviour under global atmospheric change Global Change Biology, 10: 1820-1824.

Hamilton, J.G., Dermody, O., Aldea, M., Zangerl, A.R., Rogers, A., Berenbaum, M.R. and Delucia, E. (2005). Anthropogenic changes in tropospheric composition increase susceptibility of soybean to insect herbivory. Environ. Entomol., 34: 2479-485.

Hill MG and Dymock JJ 1989. Impact of Climate Change: Agricultural/ Horticultural Systems. DSIR Entomology Division Submission to the New Zealand Climate Change Program. Auckland, New Zealand: Department of Scientific and Industrial Research.

Kannan R and James DA 2009. Effects of climate change on global diversity: a review of key literature. Trop. Eco. 50: 31-39.

Kiritani K 2005. Predicting impacts of global warming on population dynamics and 
distribution of arthropods in Japan. Popu. Eco. 48: 5-12.

Saini TM, Patel GM, Jat MK. Efficacy of Farmers innovative plant protection practices against some pestsof cotton. Pestology. 2010; 34:46-51.

Scott, N.J., Gregory, P.J., Mcnicol, J.W., Oodally, Y., Zhang, X. and Murray, P.J. (2010). Effects of soil conditions and drought on egg hatching and larval survival of the clover root weevil (Sitona lepidus). Appl. S. Ecol., 44: 75-79.

Sharma HC 2002. Host plant resistance to insects: Principles and practices. Pages 37-63 in Resources Management in Plant Protection (Sarath BB, Varaprasad KS, Anitha K, Rao P, R.D.V.J, and Chandurkar, PS, eds.). Volume 1. Rajendarnagar, Hyderabad, Andhra Pradesh, India: Plant Protection Association of India.

Sharma HC 2002. Host plant resistance to insects: Principles and practices. Pages 37-63 in Resources Management in Plant Protection (Sarath BB, Varaprasad KS, Anitha K, Rao P, R.D.V.J, and Chandurkar, PS, eds.). Volume 1. Rajendarnagar, Hyderabad, Andhra Pradesh, India: Plant Protection Association of India.

Sharma HC, Srivastava CP, Durairaj C and Gowda CLL 2010. Pest management in grain legumes and climate change. In: Climate Change and Management of Cool Season Grain Legume Crops (Yadav
SS, McNeil DL, Redden $R$ and Patil SA, eds.). Dordrecht, The Netherlands: Springer Science + Business Media. pp. 115-140.

Sharma HC, Srivastava CP, Durairaj C and Gowda CLL 2010. Pest management in grain legumes and climate change. In: Climate Change and Management of Cool Season Grain Legume Crops (Yadav SS, McNeil DL, Redden $R$ and Patil SA, eds.). Dordrecht, The Netherlands: Springer Science + Business Media. pp. 115-140.

Sharma, H. C. (2010). Global Warming and Climate Change: Impact on Arthropod Biodiversity, Pest Management, and Food Security Global Warming and Climate Change: Impact on Arthropod Biodiversity, Pest Management, and Food Security. In: National Symposium on Perspectives and Challenges of Integrated Pest Management for Sustainable Agriculture, 19-21 Nov 2010, Solan.

Thomas, M.B. and Blanford, S. (2003).Thermal biology in insect parasite interactions. Trends Ecol. Evol., 18:344-350

Thomas, M.B. and Blanford, S. (2003). Thermal biology in insect parasite interactions. Trends Ecol. Evol., 18: 344-350.

Yamamura K and Kiritani K 1998. A simple method to estimate the potential increase in the number of generations under global warming in temperate zones. Appl. Ent. Zool. 33: 289-98.

\section{How to cite this article:}

Lipsa Dash. 2020. Effect of Climate Change on Insect Behaviour. Int.J.Curr.Microbiol.App.Sci. 9(02): 1667-1672. doi: https://doi.org/10.20546/ijcmas.2020.902.192 